ISSN 0103-5150

Fisioter. Mov., Curitiba, v. 28, n. 1, p. 23-30, Jan./Mar. 2015

Licenciado sob uma Licença Creative Commons

DOI: http://dx.doi.org.10.1590/0103-5150.028.001.A002

\title{
Effect of cryotherapy on the ankle temperature in athletes: ice pack and cold water immersion
}

\author{
Efeito da crioterapia na temperatura do tornozelo \\ de atletas: pacote de gelo e crioimersão
}

\section{Vanessa Batista da Costa Santos, Camila dos Santos Cardoso, Camila Pelegrin Figueiredo, Christiane de Souza Guerino Macedo*}

Universidade Estadual de Londrina (UEL), Londrina, PR, Brazil

\begin{abstract}
Introduction: Cryotherapy is often used for rehabilitation of injured athletes. Objective: To compare the effectiveness of ice pack (IP) and cold water immersion (CWI) on lowering the ankle skin surface temperature in athletes. Materials and methods: Thirteen athletes (seven women and six men), age $19.53( \pm 2.9)$ years. IP and CWI were applied on the anterior talofibular ligament (ATFL) of the dominant leg for 30 minutes. The skin surface temperature was measured with an infrared digital thermometer prior to the application and during cryotherapy $(10,15,20,25$ and 30 minutes) and up to two hours of rewarming. During rewarming, the athletes remained at rest and the temperature was measured every 1 minute until 10 minutes, every 5 minutes for up to an hour and every 15 minutes until 2 hours. Results: The two types of cold application were effective in lowering the skin surface temperature after the 30-minute procedure. Significant differences were observed among the following temperatures: pre-application (IP $=29.8 \pm 2.4^{\circ} \mathrm{C}$ and $\mathrm{CWI}=27.5 \pm$ $3{ }^{\circ} \mathrm{C}-\mathrm{P}<0.05$ ); after 30 minutes (IP $=5 \pm 2.4{ }^{\circ} \mathrm{C}$ and CWI $\left.=7.8 \pm 3{ }^{\circ} \mathrm{C}-\mathrm{P}<0.01\right)$. For rewarming, after 25
\end{abstract}

\footnotetext{
*VBCS: MSc, e-mail: vann_costa@hotmail.com CSC: Grad., e-mail: camilafit@hotmail.com CPF: Spec., e-mail: milapelegrin@gmail.com CSGM: PhD, e-mail: chmacedouel@yahoo.com.br
} 
minutes (IP $=20.8 \pm 3.3{ }^{\circ} \mathrm{C}$ and $\left.\mathrm{CWI}=18.2 \pm 2.7{ }^{\circ} \mathrm{C}-\mathrm{P}<0.04\right)$; after 45 minutes $\left(\mathrm{IP}=24.5 \pm 2.3{ }^{\circ} \mathrm{C}\right.$ and IP $=$ $\left.22.1 \pm 3.5^{\circ} \mathrm{C}-\mathrm{P}<0.05\right)$; after 75 minutes (IP $=26.4 \pm 2.2^{\circ} \mathrm{C}$ and $\mathrm{CWI}=24 \pm 2.7{ }^{\circ} \mathrm{C}-\mathrm{P}<0.02$ ). Conclusion: After the 30-minute application, both IP and CWI produced the appropriate temperature; however the application of CWI produced the lowest temperature during rewarming.

Keywords: Cryotherapy. Physiotherapy modalities. Ankle. Athletes.

\section{Resumo}

Introdução: A crioterapia é frequentemente utilizado para reabilitação de atletas lesionados. Objetivo: Objetivou-se comparar a eficácia da aplicação do pacote de gelo convencional (PG) em relação à crioimersão (CI) na diminuição da temperatura superficial da pele do tornozelo de atletas. Materiais e métodos: A amostra foi composta por 13 atletas (sete do gênero feminino e seis do masculino), idade de 19,53 ( $\pm 2,9)$ anos. O PG e a CI foram aplicados sobre o ligamento talofibular anterior do tornozelo dominante, por 30 minutos. A temperatura superficial da pele foi verificada pré-aplicação e durante a crioterapia (10, 15, 20,25 e 30 minutos) e até duas horas de reaquecimento, com termômetro digital infravermelho. Para as coletas no período de reaquecimento, os atletas permaneceram em repouso, com temperatura verificada a cada 1 minuto, até 10 minutos, a cada 5 minutos, até uma hora, e a cada 15 minutos, até duas horas. Resultados: As duas formas de aplicação de crioterapia apresentaram efetividade para a redução da temperatura superficial da pele, após os 30 minutos de procedimento. Na comparação entre os grupos, houve diferença significativa nas temperaturas: pré-aplicação $\left(P G=29,8 \pm 2,4{ }^{\circ} \mathrm{C}\right.$ e $\left.C I=27,5 \pm 3{ }^{\circ} \mathrm{C}-P<0,05\right)$; e ao fim de 30 minutos $\left(P G=5 \pm 2,4{ }^{\circ} \mathrm{C}\right.$ e $\mathrm{CI}=7,8 \pm$ $\left.3{ }^{\circ} \mathrm{C}-\mathrm{P}<0,01\right)$. Para o reaquecimento, encontrou-se: após 15 minutos $\left(\mathrm{PG}=20,8 \pm 3,3{ }^{\circ} \mathrm{C}\right.$ e $\mathrm{CI}=18,2 \pm 2,7^{\circ} \mathrm{C}-$ $P<0,04)$; após 45 minutos $\left(P G=24,5 \pm 2,3{ }^{\circ} \mathrm{C}\right.$ e $\left.C I=22,1 \pm 3,5^{\circ} \mathrm{C}-P<0,05\right)$; após 75 minutos $(P G=26,4 \pm$ $2,2^{\circ} \mathrm{C}$ e $\left.C I=24 \pm 2,7^{\circ} \mathrm{C}-\mathrm{P}<0,02\right)$. Conclusão: Concluiu-se que, ao final dos 30 minutos de aplicação, $P G$ e CI alcançaram a temperatura adequada para os benefícios da crioterapia, porém a crioimersão obteve menor temperatura no período de reaquecimento.

Palavras-chave: Crioterapia. Modalidades de fisioterapia. Tornozelo. Atletas.

\section{Introduction}

Cryotherapy has been used in elite and amateur athletes to treat acute musculoskeletal injuries and to assist an athlete's recovery after strenuous exercise. The pathophysiology of soft tissue injuries is characterized by high cellular metabolism, hemorrhage, hyperemia, edema and local inflammation (1). It also causes muscle dysfunctions such as myofibril disturbance, rupture of mitochondria and sarcoplasmic reticulum, interruption of sarcolemma continuity, cellular self-digestion and cell death (2). Additionally, the response to the primary injury can lead to secondary injury, which occurs from both enzymatic and hypoxic mechanisms in the cells on the periphery of the primary injury (3).

Physiological and clinical evidence suggest that the primary response of the body to cold application is the reduction in temperature of the superficial tissues, accompanied by a reduction in the speed of nerve conduction, muscle cramp, muscle activity levels of metabolic enzymes, inhibition of nociceptors (4) and reduced local blood flow (5). Considering the pathophysiology of the soft tissue injuries, it was found that cryotherapy reduces the inflammatory reaction after trauma (6), slows the formation of edema (7), reduces the local metabolism and minimizes the degree of tissue injury (8), the secondary hypoxia injury (9) and pain $(4,10)$.

After 10 minutes of cold application, the surface temperature increases probably due to removal of the ice pack, the skin exposure to room temperature and to hemodynamic changes between the cooled tissue and adjacent tissues with higher temperature, which results in rewarming. It is estimated that the rewarming period lasts at least two hours after using cryotherapy (11-13). 
Several procedures are described for the application of cryotherapy (gels, sprays, ice packs, immersion, etc). However, in clinics and hospitals and in sports medicine, ice packs are the most commonly used treatment (14). Previous studies have proved the efficacy in the reduction of tissue temperature (15-18). For cooling depth, it was demonstrated that the ice pack applied to the ankle joint for 20 minutes has caused physiological changes in at least $1 \mathrm{~cm}$ (14).

Cryotherapy has been mainly used in athletes after sports practice to reduce the damage caused by strenuous exercise. Gregson et al. (19) compared the immersion in cold water in two different temperatures $\left(8{ }^{\circ} \mathrm{C}\right.$ and $22{ }^{\circ} \mathrm{C}$ ) and found that both temperatures produced lower rectal and skin surface temperature. These temperatures also reduced the arterial blood flow in 30\% immediately after cold water immersion, and in $40 \%, 30$ minutes after the procedure is complete, with more significant reductions in immersion at $8{ }^{\circ} \mathrm{C}$. Systematic review studies observed that the most frequently used temperature of water immersion ranged from $10^{\circ} \mathrm{C}$ and $15^{\circ} \mathrm{C}$, in 5 and 24 minutes, respectively $(20,21)$. It is believed that the cold water immersion is an adequate treatment for acute ankle sprain as it is able to cover the largest area of the distal end of the lower limb.

Given the widespread use of ice pack and cold water immersion in sports, further studies are necessary to compare these two types of methods and point out possible differences. Thus, the objective of this study was to analyze the effect of conventional ice pack compared to cold water immersion on decreasing the skin superficial temperature in athletes, as well as on the period of rewarming and systemic effect.

\section{Materials and methods}

This was a randomized cross-over study. Thirteen athletes (seven women and six men), mean age 19.53 $( \pm 2.9$ ) years, BMI between18.5 to 25 (normal index according to the World Health Organization), without injuries or complaints in the ankle of the dominant leg in the last six months participated in the study. Participants were excluded if they had above or below the average BMI normal value (17).

This study was approved by the Research Ethics Committee-UEL (case No 222/08). All participants were informed about the study and agreed to participate by providing their free and informed consent.
The athletes underwent cryotherapy with the application of a $300 \mathrm{~g}$ ice pack (IP) (17) for 30 minutes over the anterior talofibular ligament (ATFL) of the dominant lower limb $(14,22,23)$. Additionally, the participants immersed their ankle in a recipient with water level at $10 \mathrm{~cm}$ above the lateral malleolus, with the temperature ranging from 0 to $5{ }^{\circ} \mathrm{C}$ during the same time period (24). Cryotherapy procedures were developed in two sessions, with a 72-hour lapse between them. There was a drawing to determine which procedure would be used on the first day (ice pack or the cold water immersion), therefore, the sequence of applications was randomized.

For data collection, each subject was instructed to sit for 20 minutes in a room with constant temperature of $22^{\circ} \mathrm{C}\left( \pm 1{ }^{\circ} \mathrm{C}\right)$, to stabilize skin temperature, metabolism and blood flow. Meanwhile, questions were asked to obtain anthropometric and personal data (name, age, weight, height, BMI, training time, weekly workouts, spots modality, dominance, previous injuries and the absence of injury in the ankle of the dominant limb).

At the end of the initial rest time, the skin temperature in the ATFL of the dominant ankle was measured. CWI was applied over the anteromomedial aspect of the ankle lateral to medial malleolus ( $1 \mathrm{~cm}$ distant) and the skin temperature was recorded. The temperature was measured using the Mult Temp Incoterm ${ }^{\mathrm{TM}}$ portable digital infrared thermometer (Indústria de Termômetros). The temperature was measured prior to treatment, and with 10, 15, 20, 25 and 30-minute procedure (15). After the application ended, the athlete remained at rest for two hours, in supine position; the temperature was checked at the point marked on the ligament region every minute, up to 10 minutes and every five minutes up to an hour. After the one-hour rest, the temperature was measured every 15 minutes for two hours. The same procedure was performed on the second day of collection.

Simultaneously with the use of cryotherapy, the body pre-application temperature was recorded 15 minutes and 30 minutes, using a mercury thermometer under the armpit of the dominant upper limb to evaluate the systemic effect of the cryotherapy (25).

The data were statistically analyzed and expressed in tables. The Shapiro-Wilk test was applied before the comparative analysis of the group to determine the normality of the sample. For the comparison between the methods and the data collection time, the paired Student's t-test was employed followed by 
two-way analysis of variance (ANOVA) for repeated measures and Bonferroni post hoc. The level of significance was set at $5 \%(p \leq 0.05)$. Statistical analyses were performed using Statistical Package for Social Sciences Version 20 (SPSS Inc., Chicago, Il, USA).

\section{Results}

The mean age of participants was $19.53( \pm 2.9)$ years and the anthropometric characteristics presented weight of $67.23( \pm 10.38) \mathrm{kg}$, height of 170.53 $( \pm 11.67) \mathrm{cm}$ and BMI of $23.13( \pm 2.92) \mathrm{Kg} \cdot \mathrm{m}^{-2}$. Among these athletes, $53.85 \%$ practiced athletics and $46.15 \%$ futsal. The training time was on average $6.65(3.63 \pm)$ years, $5.76( \pm 1.09)$ times a week, 14.92 $( \pm 2.28)$ hours per week. There was a $92.30 \%$ predominance of right-handed dominance. For the previous injury, $76.93 \%$ of the athletes showed an injured ankle for more than a year, among these, $72.73 \%$ were sprains, followed by tendinitis of the Achilles tendon, fibula fracture and a fibula fracture associated with ankle sprain, both with $9.09 \%$. Physiotherapy was performed in $72.73 \%$ of injuries, followed by cryotherapy with $18.18 \%$.

The mean temperature during the application of cryotherapy (IP and CWI) pre, 10, 15, 20, 25 and 30 minutes were respectively: $29.80{ }^{\circ} \mathrm{C}( \pm$ $2.47), 8.05^{\circ} \mathrm{C}( \pm 3.01), 7.29^{\circ} \mathrm{C}( \pm 3.25), 6.51{ }^{\circ} \mathrm{C}( \pm$ $3.17), 5.75{ }^{\circ} \mathrm{C}( \pm 4.07)$ and $5.06^{\circ} \mathrm{C}( \pm 2.44)$ in the ice pack group and $27.55^{\circ} \mathrm{C}( \pm 3.06), 8.70^{\circ} \mathrm{C}( \pm 0.87)$, $7.33{ }^{\circ} \mathrm{C}( \pm 1.10), 7.06{ }^{\circ} \mathrm{C}( \pm 1.69), 7.70{ }^{\circ} \mathrm{C}( \pm 2.82)$ and $7.83{ }^{\circ} \mathrm{C}( \pm 3.09)$ in the cold water immersion group. There was a significant different in comparing before and immediately after applications using IP $(\mathrm{P}<0.0001)$ and CWI $(\mathrm{P}<0.0001)$, demonstrating the effectiveness of both types of cryotherapy. However, significant differences were only found between the groups for the pre-cooling $(\mathrm{P}<0.05)$ and the 30 -minute application values $(\mathrm{P}<0.01)$, the latter with lower temperature value for the IP group (Figure 1).

The values of the skin surface temperature after the application (during rewarming time) of the two types of cryotherapy presented significant differences between methods at 15 minutes (IP $=20.8 \pm 3.3{ }^{\circ} \mathrm{C}$ and $\mathrm{CWI}=18.2 \pm 2.7^{\circ} \mathrm{C}-\mathrm{P} \leq 0.04$ ), 45 minutes (IP $=$ $24.5 \pm 2.3{ }^{\circ} \mathrm{C}$ and $\left.\mathrm{CWI}=22.1 \pm 3.5^{\circ} \mathrm{C}-\mathrm{P} \leq 0.05\right)$ and after 75 minutes (IP $=26.4 \pm 2.2^{\circ} \mathrm{C}$ and CWI $=24 \pm$ $2.7{ }^{\circ} \mathrm{C}-\mathrm{P} \leq 0.02$ ) of application. Figure 2 shows the behavior of the skin superficial temperature during rewarming.

For the systemic temperature, significant difference was observed between periods or cryotherapy modalities. The skin temperature measured before the application of ice pack was $36.52{ }^{\circ} \mathrm{C}( \pm 0.37)$, at 15 minutes, $36.50{ }^{\circ} \mathrm{C}( \pm 0.47)$ and at 30 minutes, $36.48{ }^{\circ} \mathrm{C}( \pm 0.50)$. Temperatures recorded after the application of CWI were $36.47^{\circ} \mathrm{C}( \pm 0.37), 36.50{ }^{\circ} \mathrm{C}$ $( \pm 0.34)$ and $36.51{ }^{\circ} \mathrm{C}( \pm 0.43)$, respectively.

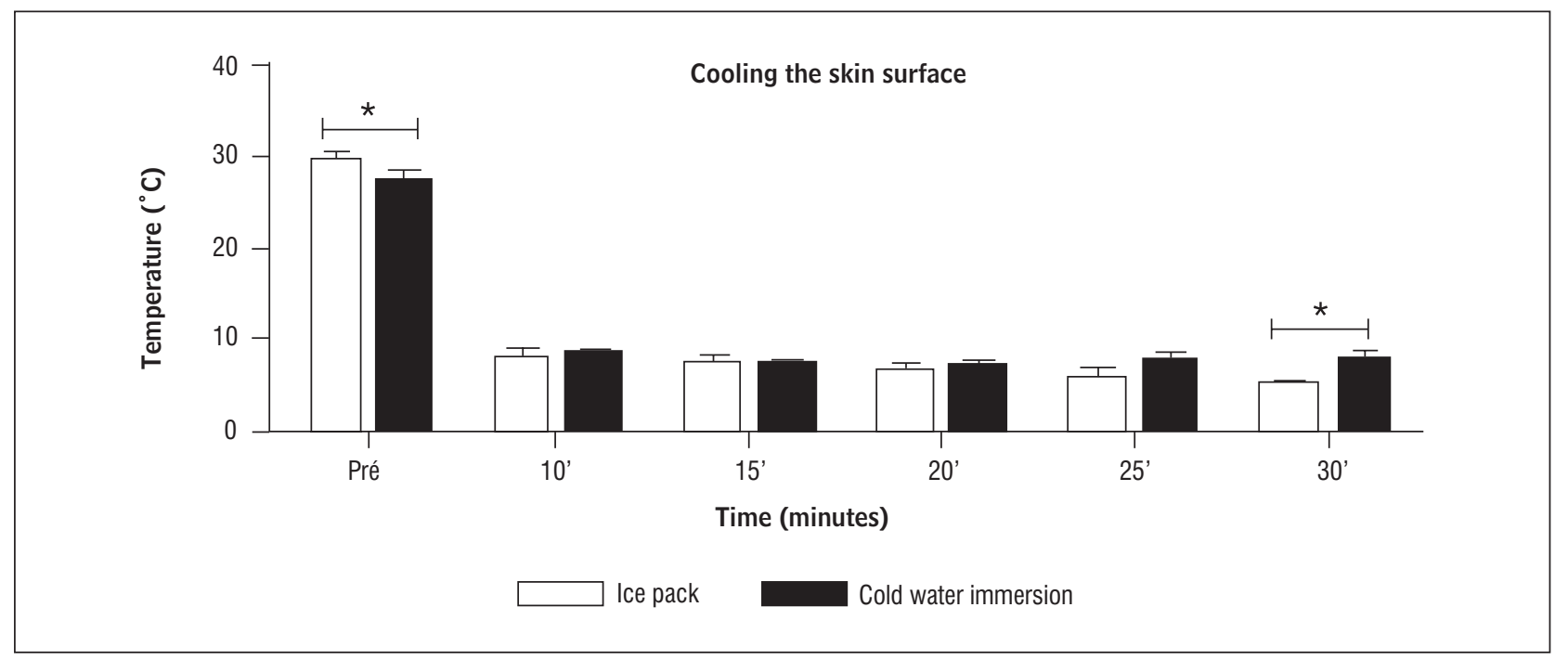

Figure $\mathbf{l}$ - Mean and standard deviation of the skin temperature over the anterior talofibular ligament of the ankle measured during the application of both cryotherapy methods

Note: * $P \leq 0.05$. 


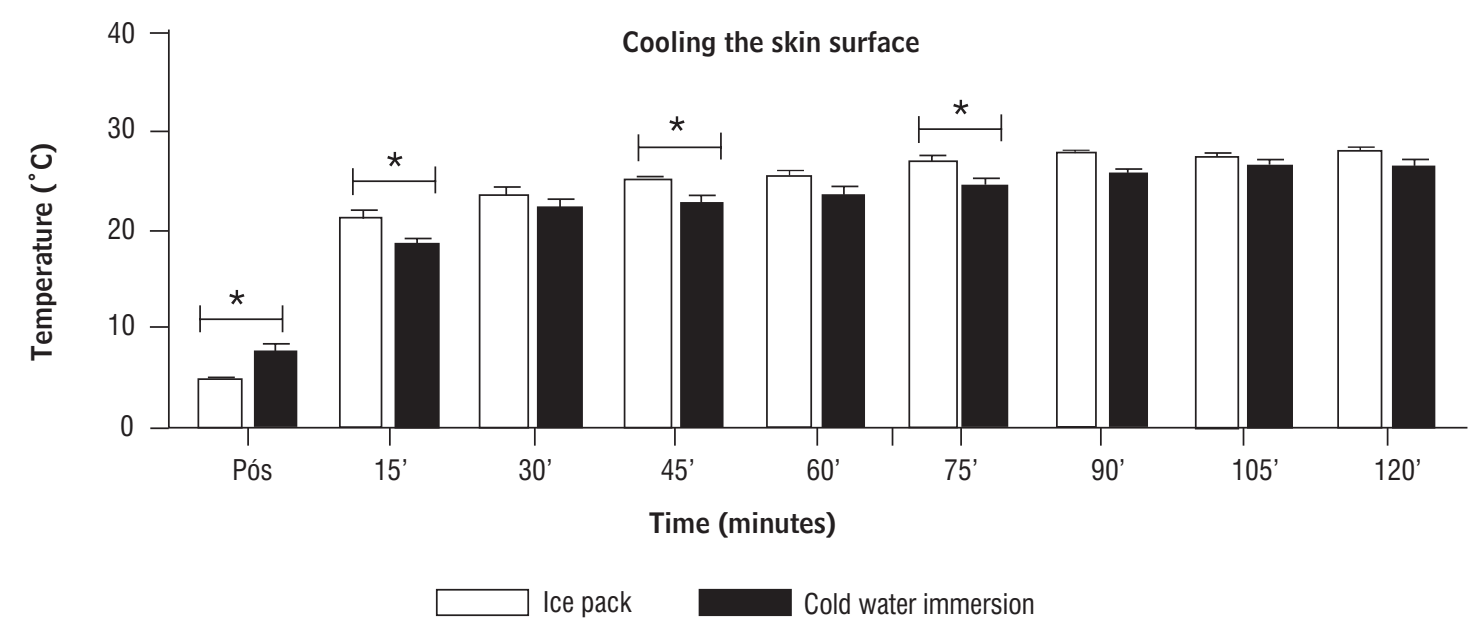

Figure 2 - Mean and standard deviation of the skin temperature over the anterior talofibular ligament of the ankle measured after the application of cryotherapy

Note: ${ }^{*} \mathrm{P} \leq 0.05$.

\section{Discussion}

The results of this study suggest both types of application, icepack and cold water immersion, were effective in reducing the skin surface temperature of the ankle in athletes, considering that temperatures below $10{ }^{\circ} \mathrm{C}$ after 30 minutes of application were observed, which confirms the physiological effects and indication for the use of this therapeutic modality. Leventhal et al. (15) reported that when ice applications are used directly on the skin, the tissue cooling is generally superficial and can range from $1^{\circ} \mathrm{C}$ to $10^{\circ} \mathrm{C}$, where the effects of cryotherapy are beneficial. Previous studies have established that the analgesic effects begin after the skin temperature reaches approximately $14.4^{\circ} \mathrm{C}(26)$, or when it is lower than $10^{\circ} \mathrm{C}$ (10) by reducing the number and speed of painful impulses sent to the brain by the peripheral nerves (4, 15). The local blood flow decreases when the tissue temperature reaches $13.8^{\circ} \mathrm{C}(26)$ to help control the formation of edemas, blood leak by injured vessels (14) and tissue hemorrhage (2). A reduction of the metabolic enzyme activity in $50 \%$ occurs in temperatures between $10{ }^{\circ} \mathrm{C}$ and $11^{\circ} \mathrm{C}(27)$. When associated with the decrease in the number of leukocytes in the injured site, this reduction can reach over $50 \%$ (8).

Even with frequent use of cryotherapy in sports injuries, however, there are still questions with regard to the differences in the cooling capacity of the different methods of application, and a direct comparison between these methods becomes necessary. A few available studies report comparisons of the same protocol and many studies do not control the heterogeneous characteristics of individuals (age, thickness of skin tissue) as well as the physical characteristics of the cold modality applied (size/ area, weight) (16).Therefore, the present study was developed with the use of $300 \mathrm{~g}$ ice pack (17) and CWI with water level at $10 \mathrm{~cm}$ above the lateral malleolus in all athletes with normal BMI in an attempt to reduce the interference of adipose tissue (28) in cooling and rewarming the superficial skin. It is known that individuals with thicker skin require a longer period of cold application to produce similar temperature changes $(17,29-31)$.

Thus, it is important to know the cooling effects provided by each modality of ice application used for the optimization of clinical response and appropriate use (32); in their study, Costello et al. (33) suggested that further research is necessary for structuring guidelines and specific protocols. Therefore, this study used an infrared thermometer to compare the effects of IP and CWI application on skin surface temperature because it is safer and noninvasive (29). The results showed that both modalities presented significant reductions in skin surface temperature at the end of 30-minute application; however, the ice pack has produced higher tissue cooling when compared 
to cold water immersion ( $\mathrm{P} \leq 0.01)$, which agrees with the study of Kennet et al. (12). Additionally, Tomchuk et al. (34) analyzed the superficial and deep temperature during and after the ice pack application and concluded that immediately after the removal, the skin surface starts to rewarm, while the intramuscular temperature continues to reduce for approximately 5 to 10 minutes.

Our study has also analyzed the time of rewarming and observed lower skin surface temperatures when CWI was applied after 15, 45 and 75 minutes of removal. Myrer et al. (35) compared the superficial and deep cooling and rewarming effects caused by the IP and CWI in whirlpool, and in agreement with our findings, they observed a significant reduction in skin surface temperature in the group submitted to IP. However, the cold immersion treatment reached the deeper tissues, maintaining the intramuscular cooling even after the removal, which did not occur in the group submitted to the ice pack. Moreover, Herrera et al. (16) compared the three modalities (cold water immersion ice pack and massage with ice) and concluded that these methods caused the reduction in skin temperature and in the nerve conduction speed, nonetheless, CWI presented better results and was considered the most effective method for local analgesia.

No significant differences were found in systemic temperature values of the individuals studied, which shows that the cooling of the distal region of the lower limb did not produce effects throughout the body, only locally. Several studies have observed reductions in the systemic temperature after cryotherapy, however, in these studies a greater body area was exposed to cold $(19,36)$, which may explain the different results found.

\section{Conclusion}

It was observed that at the end of 30 minutes of ice pack and cold water immersion application, the skin temperature reaches appropriate values to promote analgesia, control of the inflammatory process, decreased metabolism and nerve conduction, according to the literature. Additionally, the ice pack application presented lower values of skin surface temperature in the ankle region at the end of 30 - minute application.
However, during the 2 hour rewarming period, cold water immersion was able to produce lower temperatures, which should be considered in the acute phase of ankle injuries in athletes.

\section{References}

1. Brancaccio N, Klein AA, Böettche GA, Colla PHS, Machado DM, Moser GR, et al. Análise de lesão muscular em ratos treinados e sedentários submetidos a crioterapia. Fisioter Mov. 2005;18(1):59-65.

2. Matheus JPC, Milani JGPO, Gomide LB, Volpon JB, Shimano AC. Análise biomecânica dos efeitos da crioterapia no tratamento da lesão muscular aguda. Rev Bras Med Esporte. 2008;14(4):373-5. doi: 10.1590/ S1517-86922008000400010.

3. Oliveira NML, Gava AD, Salvini TF. O efeito da crioterapia e compressão intermitente no músculo lesado de ratos: uma análise morfométrica. Rev Bras Fisioter. 2007;11(5):403-09. doi: 10.1590/ S1413-35552007000500012.

4. Algafly AA, George KP. The effect of cryotherapy on nerve conduction velocity, pain threshold and pain tolerance. Br J Sports Med. 2007;41(6):365-69.

5. Manso JMG, Matoso DR, Ruiz DR, Saa SSY, Calderón J. Effect of cold-water immersion on skeletal muscle contractile properties in soccer players. Am J Phys Med Rehabil. 2011;90(5):356-63. doi: 10.1097/ PHM.0b013e31820ff352.

6. Cameron MH, editor. Physical agents in rehabilitation: from research to practice. Philadelphia: WB Saunders; 1999.

7. Deal DN, Tipton J, Rosencrance E, Curl WW, Smith TL. Ice reduces edema. A study of microvascular permeability in rats. J Bone Joint Surg Am. 2002; 84-A(9):1573-8.

8. Capps SG, Mayberry B. Cryotherapy and intermittent pneumatic compression for soft tissue trauma. IJATT. 2009;14(1):2-4.

9. Merrick MA, Rankin JM, Andres FA, Hinman CL. A preliminary examination of cryotherapy and secondary injury in skeletal muscle. Med Sci Sports Exerc. 1999;31(11):1516-21. 
10. Singh $\mathrm{H}$, Osbahr DC, Holovacs TF, Cawley PW, Speer KP. The efficacy of continuous cryotherapy on the postoperative shoulder: a prospective, randomized investigation. J Shoulder Elbow Surg. 2001;10(6):522-5.

11. Chesterton LS, Foster NE, Ross L. Skin temperature response to cryotherapy. Arch Phys Med Rehabil. 2002;83(4):543-9.

12. Kennet J, Hardaker N, Hobbs S, Selfe J. Cooling efficiency of 4 common cryotherapeutic agents. J Athl Train. 2007;42(3):343-8.

13. Pastre CM, Bastos FN, Netto Junior JN, Vanderlei LCM, Hoshi RA. Métodos de recuperação pós-exercício: uma revisão sistemática. Rev Bras Med Esporte. 2009;15(2):138-44.

14. Enwemeka CS, Allen C, Avila P, Bina J, Konrade J, Munns S. Soft tissue thermodynamics before, during, and after cold pack therapy. Med Sci Sports Exerc. 2002;34(1):45-50.

15. Leventhal LC, Bianchi RC, Oliveira SMJV. Ensaio clínico comparando três modalidades de crioterapia em mulheres não grávidas. Rev Esc Enferm USP. 2010;44(2):339-45. doi: 10.1590/S008062342010000200014 .

16. Herrera E, Sandoval MC, Camargo DM, Salvini TF. Motor and sensory nerve conduction are affected differently by ice pack, ice massage, and cold water immersion. Phys Ther. 2010;90(4):581-91.

17. Kanlayanaphotporn R, Janwantanakul P. Comparison of skin surface temperature during the application of various cryotherapy modalities. Arch Phys Med Rehabil. 2005;86(7):1411-5.

18. Fang L, Hung CH, Wu SL, Fang SH, Stocker J. The effects of cryotherapy in relieving postarthroscopy pain. J Clin Nurs. 2001;21(5-6):636-43.

19. Gregson W, Black MA, Jones H, Milson J, Morton J, Dawson B, et al. Influence of cold water immersion on limb and cutaneous blood flow at rest. Am J Sports Med. 2011;39(6):1316-23. doi: $10.1177 / 0363546510395497$.

20. Bleakley C, McDonough S, Gardner E, Baxter GD, Hopkins JT, Davison GW. Cold-water immersion (cryotherapy) for preventing and treating muscle soreness after exercise. Cochrane Database Syst Rev. 2012;2:CD008262. doi: 10.1002/14651858.
21. Bleakley CM, Costello JT, Glasgow PD. Should athletes return to sport after applying ice? A systematic review of the effect of local cooling on functional performance. Sports Med. 2012;42(1):69-87.

22. Patterson SM, Udermann BE, Doberstein ST, Reineke DM. The effects of cold whirlpool on power, speed, agility, and range of motion. J Sports Sci Med. 2008; 7(3):387-94.

23. Surenzok O, Aytar A, Tüzün EH, Akman MN. Cryoterapy impairs knee joint position sense and balance. Isokinet Exerc Sci. 2008;16(1):69-73.

24. Evans TA, Ingersoll C, Knight KL, Worrell T. Agility following the application of cold therapy. J Athl Train. 1995;30(3):231-4.

25. Khanmohammadi R, Someh M, Ghafarinejad F. The effect of cryotherapy on the normal ankle joint position sense. Asian J Sports Med. 2011;2(2):91-8.

26. Starkey C. Recursos terapêuticos em fisioterapia. São Paulo: Manole; 2001.

27. Zachariassen KE. Hypothermia and cellular physiology. Arctic Med Res. 1991;50(Suppl 6):13-7.

28. Bleakley CM, Glasgow P, Webb MJ. Cooling an acute muscle injury: can basic scientific theory translate into the clinical setting? Br J Sports Med. 2012;46(4):296-8.

29. Jutte LS, Merrick MA, Ingersoll CD, Edwards JE. The relationship between intramuscular temperature, skin temperature, and adipose thickness during cryotherapy and rewarming. Arch Phys Med Rehabil. 2001;82(6):845-50.

30. Otte JW, Merrick MA, Ingersoll CD, Cordova M. Subcutaneous adipose tissue thickness alters cooling time during cryotherapy. Arch Phys Med Rehabil. 2002;83(11):1501-5.

31. Bleakley CM, McDonough S, MacAuley D. The use of ice in the treatment of acute soft-tissue injury : a systematic review of randomized controlled trials. Am J Sports Med. 2004;32(1):251-61.

32. Carvalho AR, Medeiros DL, Souza FT, Paula GF, Barbosa PM,Vasconcellos PRO, et al. Variação de temperatura do músculo quadríceps femoral exposto a duas modalidades de crioterapia por meio de termografia. Rev Bras Med Esporte. 2012;18(2):109-11. 
33. Costello JT, McInerney CD, Bleakley CM, Selfe J, Donnelly AE. The use of thermal imaging in assessing skin temperature following cryotherapy: a review. J Therm Biol. 2012;37(2):103-10.

34. Tomchuk D, Rubley MD, Holcomb WR, Guadagnoli M, Tarno JN. The magnitude of tissue cooling during cryotherapy with varied types of compression. J Athl Train. 2010;45(3):230-7. doi: 10.4085/1062-6050-45.3.230.

35. Myrer W, Meason G, Fellingham GW. Temperature changes in the human leg during and after two methods of cryotherapy. J Athl Train. 1998;33(1):25-9.
36. Savalli L, Olave P, Sendin MIH, Laboute E, Trouvé $\mathrm{P}$, Puig PL. Cryothérapie corps entier à $-110{ }^{\circ} \mathrm{C}$. Mesure des températures cutanées et centrale chez le sportif. Sci Sports. 2006;21(1):36-8. doi: 10.1016/ j.scispo.2006.01.005.

Received: $12 / 07 / 2013$ Recebido: 07/12/2013

Approved: 07/15/2014 Aprovado: 05/07/2014 